Received: December 08, 2021

Accepted: February 16, 2022

${ }^{*}$ Corresponding author:

Hertha Bastiawan, Magister

Management, Mercu Buana

University, Jakarta, Indonesia

E-mail:

herthabastiawan@gmail.com

Additional information is available at the end of the article

\title{
Analysis of Healthy Living Behavior, Age, and Income on Gluten-Free Food Consumption
}

\author{
Hertha Bastiawan ${ }^{1 *}$, Sugeng Santoso ${ }^{2}$, Achmad Indra Sahab ${ }^{3}$, Abdul Yamin ${ }^{4}$, Beta \\ Almira ${ }^{5}$
}

Abstract: This research was triggered by the phenomenon of an increase in people adopting a healthy lifestyle during the COVID-19 pandemic. People who adopt a healthy lifestyle are assumed to consume healthy food such as gluten-free food. Meanwhile, as people grow older and their income improves, the desire to consume gluten-free food also increases. This research aims to analyze healthy behavior, age, and income on the desire to consume gluten-free foods that Logit Model constructed. Gluten-free foods can be defined as foods that do not contain gluten substances such as wheat, and they can be classified as healthy food because people who consume this food can avoid some diseases. The study determined Logit Model and used quantitative methods and convenience sampling based on the SPSS application. From 10 to 12 October 2021, research collected 193 respondents, mainly from the Jabodetabek area. Using Wald Test, the study formed a Logit Model for this relationship. In conclusion, healthy living behavior, age, and income partially and simultaneously influence gluten-free food consumption. By observing this study, entrepreneurs in the food sector are expected to produce gluten-free food.

Keywords: age, gluten-free food, healthy living behavior, income, logit model

JEL Classification: E21, I1, I12

\section{ABOUT THE AUTHORS}

Hertha Bastiawan graduated from Industrial Engineering, Institut Teknologi Bandung, Indonesia. His areas of specialization include central banking treasury system operation. He can be reached via herthabastiawan@gmail.com.

Sugeng Santoso is an Associate Professor at the Faculty of Economy and Business, Mercu Buana University, Indonesia. He was awarded as The Best Performing Lecturer on Magister Program of Mercu Buana University Academic Year 2019-2020. His areas specialization includes creative food startup and industrial cluster. He can be reached via sugeng.santoso@mercubuana.ac.id.

Hertha Bastiawan
A. Indra Sahab graduated from the National Institute of Science \& Technology (ISTN), Jakarta. His areas of specialization include sales and management of building materials. He can be reached via a.indrasahab@gmail.com.

Abdul Yamin holds a degree in Financial Accounting from the Faculty of Economics and Business, Mercu Buana University, Jakarta, Indonesia. His areas of specialization include financial calculations and Financial Reporting Services. He can be contacted via abdulyamin34@gmail.com.

Beta Almira is a Bachelor's Degree in Aeronautical Engineering, Faculty of Engineering, ITDA University, Indonesia. Her areas of specialization include Design Organization Approval and Field Engineering Services. She can be reached via betaalmira@gmail.com.

\section{PUBLIC INTEREST STATEMENT}

Research has the advantage of combining healthy food consumption habits with healthy lifestyles and other factors in the form of age and income levels.

Research can develop healthy food and beverages ecosystem and also encourage an increasing quantity of healthy food industry/entrepreneurship. Within the industrial cluster, the healthy food industry is the core industry surrounded by the ecosystem and value chain. 


\section{Introduction}

Gluten is a substance in grains, especially wheat and barley, creating an elastic texture in dough. Gluten can also be found in processed foods, such as pasta, bread, and cereals. So, gluten-free foods can be defined as foods that do not contain gluten elements. However, frequent gluten consumption can cause flatulence, diarrhea, abdominal pain, weight loss, feeling weak, anemia, osteoporosis, or celiac disease. Global market data indicate that gluten-free product sales are forecasted to increase by a compound annual growth rate of 8.3 percent between 2020 to 2025 . The projected market size will reach USD 8.1 billion in 2025 (Markets \& Markets, 2021). The market is driven by the rising prevalence of celiac disease, the growing population shifting towards healthier diets, and the labeling standards of gluten-free products.

During the last decade, gluten-free food utilization has turned into a far-reaching diet pattern because of the consciousness of gluten prejudices/sensitivities, as better indicative devices are opening up, and on account of the expanded number of customers following this eating regimen to clinical necessities. According to Zoumpopoulou and Tsakalidou (2019), many techniques can be applied in the production of gluten-free foods, namely by adding additives in the formulation, bioprocess fermentation, and optimal processing technology and GMO methodologies. Gluten-free foods had grown from a niche market, and many conventional stores played an essential role in distributing gluten-free products, and this category accounted for the largest share (Masih \& Sharma, 2016). Due to the increasing producers and the distribution channel of gluten-free foods, consumption of this food also increases accordingly.

In fighting the COVID-19 disease, maintain the immune system, primarily to control comorbid diseases (Ministry of Health of the Republic of Indonesia, 2020). Several things can increase self-immunity in people exposed to COVID-19, namely as follows: consumption of balanced nutrition, physical activity, adequate rest, vitamin supplements, not smoking activity, and controlling comorbidities. A healthy lifestyle is a way of life that reduces the risk of severe illness or premature death. Not all diseases can be prevented, but most deaths, especially those caused by coronary heart disease and lung cancer, are avoidable. Health is not just about avoiding disease. It is also about physical, mental, and social well-being. When a healthy lifestyle is adopted, more positive role models are assigned to others in the family, especially children (World Health Organization, 1999).

Indonesia has been experiencing a COVID-19 pandemic since March 2020. This pandemic requires sufferers to maintain good immunity and prevent immunity. One way to maintain immunity is to adopt a healthy lifestyle is exercising regularly and maintaining the quantity of sleep. Since the pandemic, the number of perpetrators of healthy living has increased, as can be seen from the crowds of people cycling and running near residential areas. Food manufacturers have made several breakthroughs to produce healthy food products to support a healthy lifestyle. One of the healthy food products is free from gluten elements. Therefore, people who often do a healthy lifestyle are expected to maintain their food patterns through efforts to consume healthy foods such as gluten-free food.

Previous studies regarding gluten-free food limited only observation of price. Many studies in different countries stated that the price of gluten-free products was higher compared to gluten-containing products such as on United Kingdom market (Fry, Madden, \& Fallaize, 2018), Canadian market (Khoury, Balfour-Ducharme, \& Joye, 2018), and Norway market (Myhrstad et al., 2021). The more expensive gluten-free products can make this type of food limited. We estimate that consumers need a decent income to consume gluten-free food regularly. If the consumer's income meets basic needs, they will consume gluten-contain food at an affordable price. Based on this condition, income level is one factor that influences gluten-free food consumption.

On the other hand, other studies are limited by observing the age factor on the choice of gluten-free food or healthy food. Older consumers are estimated to consume 
healthy foods, one of which is a gluten-free food. In Greenland, age is one factor that influences dietary habits (Wielsoe et al., 2021). One dietary habit mechanism is to consume gluten-free food rather than gluten-containing food. In community-dwelling older adults, diets are of better quality (Bloom et al., 2016). So, as age grows older, people will tend to choose gluten-free food as healthy food more frequently.

This research is unique because it observes gluten-free food consumption from more than one variable: healthy living behavior, age, and income. The previous study only partially focuses on the relationship between purchasing decisions affected by lifestyle and positive word of mouth (Nugroho \& Nikmah, 2018). Meanwhile, another research only focuses on the cost comparison between gluten-free food and glutencontain food, not bringing up the cost itself that can influence the consumption of gluten-free food (Fry, Madden, \& Fallaize, 2018). According to Littlejohns et al. (2020), regarding income level, gluten-free diet enthusiasts were female, non-white, highly educated, lived in a poorer area, lost weight in the previous year, had poorer personal health.

This research aims to determine whether a healthy lifestyle, age, and income simultaneously and partially have a significant effect on the level of consumption of gluten-free foods. In addition, this research aims to determine the logistic regression (logit) model of that relationship. This model is applied almost when explaining that the dependent variable is not continuous but binary - dichotomous or alternative to take only two values. They are applicable in various fields and are used extensively in the survey or census-type data. For example, if the company prospers, it is the value one, and if the company is declared bankrupt, it is 0 .

For this reason, we cannot use "classic" regression but adjusted regression analysis, called Logit models (Klieštik, Kočišová, \& Mišanková, 2015). Logit and probit models guarantee that estimated probabilities lie in the 0-1 range and are nonlinear to the explanatory variable (Santoso, 2010). We hope the healthy food and beverages ecosystem can encourage an increasing quantity of healthy food industry/entrepreneurship and encourage the healthy food industry to enhance product diversification to attract more consumers. Within an industrial cluster, the healthy food industry is the core industry surrounded by the ecosystem and value chain. We hope this research has benefited the food and beverage industry, and the government can provide support for increasing stock and providing particular incentives for gluten-free food producers in the future.

\section{Literature Review}

Gluten is the protein that occurs naturally in wheat, rye, barley, and crosses of these grains. As many as three million people worldwide suffer from the disorder (Food \& Drug Administration, 2013). It happens when the body's normal ammo responds to the protein by assaulting the coating of the small digestive tract. While not a solid, gooey layer, the body cannot retain the supplements it needs. Deferred development and wholesome inadequacies can prompt conditions like sickliness (underneath the customary red platelet reach) and pathology, sicknesses in which bones become fragile. Many give off an impression of being compromised. Other genuine medical issues might incorporate polygenic infection, response thyroid sickness, and viscus disease. Before the rule, there were no federal standards or definitions for food businesses used in labeling merchandise "gluten-free." Five percent of foods currently marked "gluten-free" contain twenty parts per million (ppm) of protein.

Wheat/gluten-related diseases can be classified into three different disorders such as autoimmune, allergic, and neither autoimmune nor allergic (Sabença et al., 2021). Celiac disease is the most prominent autoimmune gluten-related disorder (CD). It is a condition of the small intestine caused by gluten and gluten-related proteins and influenced by environmental and genetic factors (Gujral, Freeman, \& Thomson, 2012; Cabanillas, 2020.). An IgE (Immunoglobulin E) and non-IgE mediated immune response characterize wheat allergy (WA), resulting in an allergic reaction in some individuals upon contact, inhalation, or uptake of foods containing wheat. However, IgE-cross 
reactivity to other cereals is possible in some people (Czaja-Bulsa \& Bulsa, 2017.). Patients with Non-Celiac Wheat/Gluten Sensitivity (NCWGS) experience identical symptoms to CD, but they do not test positive for CD (Pinto-Sanchez \& Verdu, 2018).

The government can collaborate with some food startups as a marketplace and creative economy institutions to maintain a sufficient supply of gluten-free food for the market and implement supporting policies. A sufficient supply will encourage people to consume gluten-free food. Food startups can be used as matchmaking activities among sellers and buyers to increase added value (Santoso, 2020). Meanwhile, the creative economy largely contributes to Gross Domestic Product (GDP), especially economic growth (Santoso et al., 2021). The creative economy must be accompanied by the local business community proposed by the local government (Redata, Kezia, Solaiman, \& Santoso, 2021) and synergize with stakeholders' Collaboration Program to make the product export commodities (Santoso et al., 2021).

\subsection{Healthy Lifestyle}

A healthy lifestyle is necessary for improving health instated in expressed that a sound way of life is fundamental for making strides in well-being (Çelebi, Gündoğdu, \& Kızılkaya, 2017). Health-enhancing behaviors incorporate behaviors to be performed by people themselves to make strides in their well-being and guarantee selfactualization. A sound way of life ought to be not as it was centered on security against illnesses but the behaviors that increment well-being all through life. A sound way of life behaviors too incorporate satisfactory and adjusted slim down, push administration, satisfactory and standard works out, non-smoking, well-being duty, and clean measures. The foremost characteristic complaints of post-menopause incorporate vasomotor indications such as hot flushes, night sweating, urogenital decay, osteopenia, osteoporosis, psychiatric clutter, sexual dysfunctions, skin injuries, cardiovascular maladies, cancer, metabolic disarranges and corpulence.

All of these complaints influence the quality of life of ladies adversely. The foremost common metabolic clutters in menopause are dyslipidemia, impeded glucose resilience, affront resistance, hyperinsulinemia, and sort two diabetes (Lobo et al., 2014). So, too, reliable way of life behaviors influenced the seriousness of menopausal complaints. In pertinent thinks, it has appeared that sound way of life behaviors strongly impact decreasing menopausal complaints. The propensity of having a solid eat less and customary working out, the victory in stretch administration, the accessibility of interpersonal bolster frameworks, self-esteem, self-fulfillment and ordinary mindfulness of well-being obligation guarantee lady at this period to involvement it with fewer complaints and more consolation (Batista et al., 2018; Kocak, 2017).

Among the few existing considers of well-being ways of life in afterward adulthood (Cockerham, Wolfe, \& Bauldry, 2019) met a small number $(\mathrm{N}=21)$ of middle-class people matured 54-65 a long time in Modern Zealand who were enrolled since they were likely encountering age-related well-being issues and degenerative conditions. The members recognized that the obligation for great well-being through living a solid way of life was beneath their control and the results of the disappointment to do so. Living such a way of life was delineated as a "moral obligation." Indeed, a few members felt unreliable approximately their past ways of life, and concern around their well-being was common within another stage of life. They recognized that solid living was not simple in that "it required individual penances of pleasant, but possibly deadly foodstuffs such as butter and quick nourishment, pushing oneself to preserve satisfactory levels of wellness and standing up to liberal but untrustworthy indecencies such as sunbathing, smoking and alcohol" (Jaye et al., 2018). 


\subsection{Age}

Well-being convictions and nourishment choice variables are critical determinants of solid utilization in elderly individuals, but with distinctive impacts on sound eating behavior (Lesakova, 2018). Therefore, this investigation should be considered to progress adherence to the Gluten-Free Diet (GFD) for celiac sufferers. It is vital to recognize non-celiac individuals for GFD and Gluten-Free items in expansion. In other words, exact data approximately slim down, and items are pertinent to bolster individuals to create more good nourishment choices. Meanwhile, another research determined that older adults usually select exceptionally healthy food (Dunneram \& Jeewon, 2015). Considering that maturing is a continuous course of human existence, intercessions should be considered in grown-up life. Altered sustenance schooling programs and the improvement of utilitarian food varieties are fitting intercessions that can be executed in the Indonesian case (Sutanto, Lukito, \& Basrowi, 2020). Based on research weighted by the French census, ten $\cdot 31 \%$ of the participants declared avoiding gluten. While Perrin et al. (2019) show that women dominate participants, elderly, non-smokers, low education levels, and people experience more food intolerance. They had higher consumption of fruit, vegetables and lower dairy products, salty/sweet and fatty foods, and alcohol.

\subsection{Income Level}

Income permits individuals to purchase the fundamental fabric necessities for wellbeing (Benzeval et al., 2014). These are regularly expressed to incorporate protection, satisfactory nourishment, and sanitation is one viewpoint within the writing (Marmot, 2002). Even though not suggesting a limit for well-being, analysts have endeavored to calculate the least wage required for solid living covering both fabric and social conditions of living and found it to be over advantage/ least wage levels input at the time (Morris, Donkin, Wonderling, Wilkinson, \& Dowler, 2000; Morris, Wilkinson, Dangour, Deeming, \& Fletcher, 2007). The consistency of a glutenfree diet might be more challenging for certain families because of the critical value disparity of gluten things. Families on government assistance with individuals who require a GFD are especially powerless against food instability (Lambert \& Ficken, 2015).

Path analysis of attitudinal, motivational, demographic, and behavioral factors influencing food choice among Australian consumers who have consumed at least some organic food in the previous 12 months shows that concerns with the naturalness of food and the sensory and emotional experience of eating are the main determinants of increasing levels of organic food consumption. Income, age, political and ecological values, and willingness to pay a premium for safe and environmentally friendly food have a minimal effect (Lockie, Lyons, Lawrence, \& Gricec, 2004). Another research mentions that income level is related to diet and health-related quality (French, Tangney, Crane, Wang, \& Appelhans, 2021). A study in Cyprus examined that affordability was defined as the Gluten-free Healthy Food Basket (GFHFB) cost as a percentage of the Guaranteed Minimum Income (GMI). As a result, GFHFB was 33.6 and 47 euros/month more expensive than the other healthy basket food (Chrysostomou, Andreou, \& Andreou, 2019). This makes it difficult for low-income people to spend their income on this food. Another study in Czech concluded that raw materials of gluten-free food are costly, and an organized and monetarily adjusted scope of handled items should be found in the hospitality industry with the acknowledgment of the buying force of their purchasers (Śálková \& Hes, 2015).

\section{Conceptual Framework}

The descriptive method aims to provide a clearer picture of more specific social situations by focusing on particular aspects and showing the relationship between various variables. In comparison, the logistic regression method determines the relationship or influence of the independent and dependent variables, either individually or together. 
This research involved three independent variables, namely healthy living behavior $\left(x_{1}\right)$, age $\left(x_{2}\right)$, and income $\left(x_{3}\right)$, and one dependent variable, namely gluten-free healthy food. This research belongs to survey research type, which research correspondent to large and small populations, but the data studied are data from samples taken from that population so that relative events, distributions, and relationships between sociological and psychological variables are found (Sugiyono, 2017).

The relationship model can be described as follows:

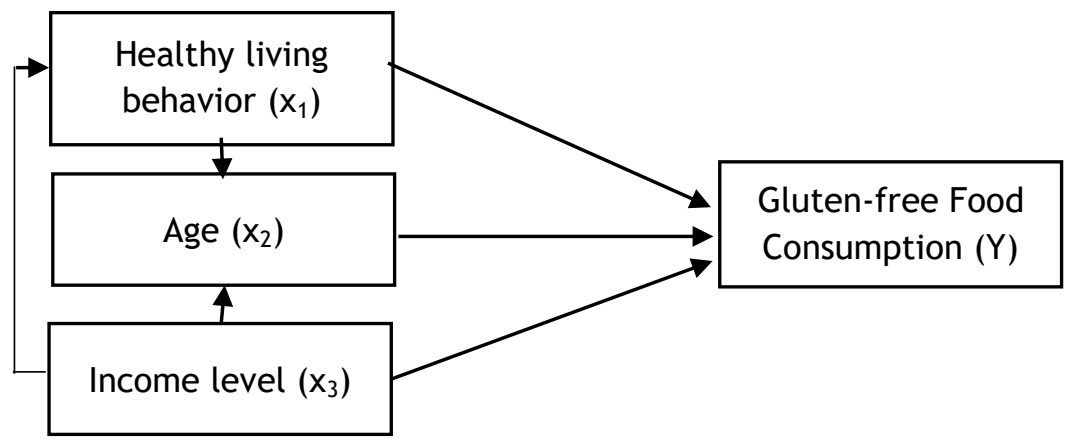

Figure 1. Conceptual framework

Based on Figure 1, the following hypothesis of this research describes as bellow:

a. The hypothesis regarding dependent variable

$\mathrm{H}_{1}$ : Healthy living behavior affect gluten-free food consumption

$\mathrm{H}_{2}$ : Age affect gluten-free food consumption

$\mathrm{H}_{3}$ : Income level affect gluten-free food consumption

b. The hypothesis regarding the formulation of the Logit model

$\mathrm{H}_{0}$ : The logit model fits (there is no significant difference between the observed results and the possible predictions of the model)

$\mathrm{H}_{1}$ : The logit model does not fit (there is a significant difference between the observed results and the possible predictions of the model)

\section{Methods}

\subsection{Participants}

Research using a quantitative method to determine the relationship of consumption of gluten-free food categorized as healthy food based on healthy living behavior, age, and income level. Research is conducted by distributing questionnaires within October 10-12, 2021. The research was conducted using the non-probability method by convenience sampling to get as many as respondents. We did not have specific criteria or pre-requisites for selecting this study's respondents. The respondents scattered from Jakarta, Bogor, Depok, Tangerang, Bekasi, some cities in West Java, Jogjakarta, some cities in East Java, and some live in Sumatra, Kalimantan, Sulawesi, and Papua area based on our colleagues. The population of this research is assumed to be 400 people representing various groups mapped based on age, gender, and income level. With a confidence level of 5 percent, a minimum of 186 data sampling is required. The total respondents of this research were 193 respondents using the google form. The use of google forms is intended to facilitate the acquisition of large numbers of respondents and avoid the spread of covid-19. Data processing to perform the analysis is used SPSS software. 


\subsection{Measurement}

This field research collected primary data using close-ended questions regarding respondents' characteristics, healthy lifestyle, age, income, and gluten-free consumption. Primary data is obtained from respondents' responses from an online survey conducted using the Google Forms web survey platform. We also asked participants to share the questionnaire link with their colleagues. The link to the online survey questionnaire was distributed through the WhatsApp application based on contacts of the team's group members. In addition, reliability testing for all questions was carried out simultaneously. The results show that the Cronbach Alpha value with 27 statements is 0.728 or greater than 0.6 . Therefore, it can be said that the questionnaire used is reliable.

There are two kinds of variables used in this study, independent variables, such as healthy lifestyle $\left(X_{1}\right)$, age $\left(X_{2}\right)$, and income $\left(X_{3}\right)$, and the dependent variables, namely gluten-free consumption $(Y)$. Healthy lifestyle questions consist of 5 dimensions: exercise, sleeping time, weight and dietary choice, smoking, and supplement purchase motivation with Cronbach Alpha 0.65. All dimensions except supplement purchase motivation were modified from Guernsey and Alderney Healthy Lifestyle Survey 2013 (Ford et al., 2014). Meanwhile, supplement purchase motivation is modified from the study regarding supplement consumption Viscecchia, Stasi, Nardone, Devitiis, \& Baselice, 2016). This variable consists of 9 closed-ended questions and uses the Guttman scale point referring to 2 alternative answers, namely Yes/Agree worth one or No/Disagree worth 0.

The second variable, age, has two dimensions: changes in habits after getting older and food consumption with Cronbach Alpha 0.63. The first dimension was modified from the Japanese Study of Aging and Retirement (Motegi, Nishimura, \& Terada, 2016). The second dimension was modified from the European Journal of Public Health (Helldán, Lallukka Rahkonen, \& Lahelma, 2011). This variable consists of nine close questions and uses the Guttman scale referring to 2 alternative answers: yes/agree worth one or no/disagree worth 0 .

The third variable, income or earning, has two dimensions with Cronbach Alpha 0.74. The first dimension is society-related features (Chen \& Antonelli, 2020). The second dimension is functional food (Sutanto, Lukito, \& Basrowi, 2020). This variable consists of 8 closed-ended questions and uses the Guttman scale, referring to 2 alternative answers: yes/agree worth one or no/disagree worth 0 . Detail questionnaire can be shown in Table 1.

Table 1. Questionnaire matrix

\begin{tabular}{|c|c|c|c|}
\hline Variables & Dimension & Operational Definition & Questions \\
\hline \multirow{5}{*}{$\begin{array}{l}\text { Healthy Lifestyle }\left(\mathrm{X}_{1}\right) \text { - One } \\
\text { thing that can increase self- } \\
\text { immunity in people exposed to } \\
\text { COVID-19, namely, physical } \\
\text { activity or a healthy lifestyle } \\
\text { (Indonesian Ministry of Health, } \\
\text { 2020) }\end{array}$} & Exercise & $\begin{array}{l}\text { How many times in the past } \\
\text { week they had taken part in } \\
\text { sport or recreational } \\
\text { activity }\end{array}$ & 3 \\
\hline & $\begin{array}{l}\text { Sleeping } \\
\text { time }\end{array}$ & $\begin{array}{l}\text { Sleep quality is based on } \\
\text { how many hours of sleep } \\
\text { they had on average }\end{array}$ & 2 \\
\hline & $\begin{array}{l}\text { Weight and } \\
\text { Dietary } \\
\text { Choice }\end{array}$ & $\begin{array}{l}\text { Weight status regarding } \\
\text { body mass index (BMI) and } \\
\text { dietary choices such as } \\
\text { fruit and vegetable } \\
\text { consumption }\end{array}$ & 2 \\
\hline & Smoking & $\begin{array}{l}\text { smoking status such as } \\
\text { never smoke or current } \\
\text { smoker and }\end{array}$ & 1 \\
\hline & $\begin{array}{l}\text { Supplement } \\
\text { purchase } \\
\text { motivation }\end{array}$ & $\begin{array}{l}\text { Supplement motivation to } \\
\text { health status, unbalanced } \\
\text { diet, or prevention attitude }\end{array}$ & 1 \\
\hline $\begin{array}{l}\text { Age }(X 2) \text { - Older adults were } \\
\text { associated with better quality } \\
\text { diets (Bloom et al., 2016). }\end{array}$ & $\begin{array}{l}\text { Changes in } \\
\text { habits after } \\
\text { getting older }\end{array}$ & $\begin{array}{l}\text { Activities and rest } \\
\text { frequencies as people get } \\
\text { older }\end{array}$ & 5 \\
\hline
\end{tabular}




\section{J O U R N A L O F CONSUMER SCIENCES}

Table 2. Questionnaire matrix (cont...)

\begin{tabular}{lllc}
\hline Variables & Dimension & Operational Definition & Questions \\
\hline & $\begin{array}{l}\text { Food } \\
\text { consumption }\end{array}$ & $\begin{array}{l}\text { Variation of food } \\
\text { consumption as people } \\
\text { get older }\end{array}$ & 4 \\
$\begin{array}{l}\text { Income or Earning }\left(\mathrm{X}_{3}\right)-\text { gluten- } \\
\text { free products' price was higher } \\
\text { than gluten-containing } \\
\text { products (Myhrstad et al., }\end{array}$ & $\begin{array}{l}\text { Society- } \\
\text { related } \\
\text { features }\end{array}$ & $\begin{array}{l}\text { Income is one of the } \\
\text { society-related features } \\
\text { that affect food choices. }\end{array}$ & 2 \\
& $\begin{array}{l}\text { Functional } \\
\text { Food }\end{array}$ & $\begin{array}{l}\text { Functional foods are } \\
\text { nutritional products } \\
\text { containing biologically } \\
\text { active compounds that } \\
\text { help maintain the } \\
\text { population's best physical, } \\
\text { mental, and mental } \\
\text { health. }\end{array}$ &
\end{tabular}

\subsection{Analysis}

In this research, we use convenience sampling. The data obtained were then inputted and processed through the stage of editing, coding, scoring, and data analysis using Microsoft Office Excel and IBM Statistical Package for Social Science (SPSS) version 25. Microsoft Office Excel is used to calculate and analyze descriptive statistics. To measure reliability, we use Cronbach Alpha 0.6 as the minimum threshold.

\section{Findings}

\subsection{Respondent Characteristics}

Total 193 respondents responded questionnaire via the Google Forms web survey platform. Most respondents are male $(57.5 \%)$ or as many as 111 respondents from the respondent characteristic. Meanwhile, the age category of respondents above 50 years dominated the respondents $(42.0 \%)$ or 81 respondents. Other characteristics are education level dominated by bachelor's degree $(70.5 \%)$ with 136 respondents, while the income level category is dominated by income below 15 million rupiahs $(63.7 \%)$ as many as 123 respondents. Finally, the number of dependents category is dominated by the number of dependents equal to or less than two people (57.5\%) as many as 111 respondents.

\subsection{Generate Logit Model}

Based on Table 2, it is known that the statistical value of the likelihood ratio test $(G)$ is 46.502 , and the $\mathrm{p}$-value is 0.006 . The value of the chi-square table with $0.05(\alpha)$ and degrees of freedom 25 is 14.6114 . Decision-making is done by comparing the pvalue of $\mathrm{G}$ as much 0.00 , which is smaller than $0.05(\alpha)$, so $\mathrm{H}_{0}$ is rejected. This means that at least one predictor variable simultaneously affects the response variable.

Table 2. Chi-square Test

\begin{tabular}{llrrr}
\hline & & Chi-square & df & Sig. \\
\hline Step 1 & Step & 46.502 & 25 & 0.006 \\
& Block & 46.502 & 25 & 0.006 \\
& Model & 46.502 & 25 & 0.006 \\
\hline
\end{tabular}

Wald test is used to generate the Logit Model of the questionnaire dominated by the binary answer. The Logit Model is formed by selecting items with lower significance than the reference $(0.005)$. We use the $B$ value for each item as an exponential factor of that variable model for selected questions. Logit Model also needs constant value on the numerator side. This constant value can be gathered from the constant parameter of the Wald Test. Wald Test also can be used to test the Significance of the Logit Model Parameters Partially. The exact value of the Wald Test provides in Table 3 . 
Table 3. Wald Test

\begin{tabular}{|c|c|c|c|c|c|c|}
\hline Code & B & S.E. & Wald & Df & Sig & $\operatorname{Exp}(B)$ \\
\hline $\mathrm{X}_{11}(1)$ & 0.408 & 0.634 & 0.413 & 1 & 0.520 & 1.503 \\
\hline$X_{12}(1)$ & 0.013 & 0.544 & 0.001 & 1 & 0.981 & 1.013 \\
\hline$X_{13}(1)$ & 0.032 & 0.608 & 0.003 & 1 & 0.959 & 1.032 \\
\hline$X_{14}(1)$ & 0.472 & 0.536 & 0.777 & 1 & 0.378 & 1.603 \\
\hline$X_{16}(1)$ & -0.212 & 0.567 & 0.139 & 1 & 0.709 & 0.809 \\
\hline $\mathrm{X}_{17}(1)$ & -0.216 & 0.524 & 0.170 & 1 & 0.680 & 0.806 \\
\hline $\mathrm{X}_{18}(1)$ & 0.263 & 0.520 & 0.255 & 1 & 0.613 & 1.300 \\
\hline $\mathrm{X}_{19}(1)$ & -0.703 & 0.474 & 2.206 & 1 & 0.137 & 0.495 \\
\hline$X_{21}(1)$ & -0.759 & 0.613 & 1.535 & 1 & 0.215 & 0.468 \\
\hline$X_{22}(1)$ & -0.500 & 0.484 & 1.067 & 1 & 0.302 & 0.606 \\
\hline$X_{23}(1)$ & -0.167 & 0.489 & 0.117 & 1 & 0.732 & 0.846 \\
\hline$X_{24}(1)$ & 0.073 & 0.955 & 0.006 & 1 & 0.939 & 1.076 \\
\hline$X_{25}(1)$ & -0.034 & 0.562 & 0.004 & 1 & 0.951 & 0.966 \\
\hline$X_{26}(1)$ & -0.400 & 0.579 & 0.478 & 1 & 0.489 & 0.670 \\
\hline$X_{27}(1)$ & -0.152 & 0.534 & 0.081 & 1 & 0.776 & 0.859 \\
\hline$X_{28}(1)$ & -0.506 & 0.573 & 0.780 & 1 & 0.377 & 0.603 \\
\hline$X_{29}(1)$ & -0.449 & 0.549 & 0.670 & 1 & 0.413 & 0.638 \\
\hline$X_{31}(1)$ & -0.975 & 0.508 & 3.688 & 1 & 0.055 & 0.377 \\
\hline$X_{32}(1)$ & 0.062 & 0.590 & 0.011 & 1 & 0.916 & 1.064 \\
\hline$X_{33}(1)$ & 0.259 & 0.498 & 0.270 & 1 & 0.603 & 1.295 \\
\hline$X_{34}(1)$ & -0.116 & 0.555 & 0.044 & 1 & 0.834 & 0.890 \\
\hline$X_{35}(1)$ & -0.919 & 0.473 & 3.781 & 1 & 0.052 & 0.399 \\
\hline$X_{36}(1)$ & 0.402 & 0.557 & 0.520 & 1 & 0.471 & 1.494 \\
\hline$X_{37}(1)$ & 0.533 & 0.541 & 0.969 & 1 & 0.325 & 1.703 \\
\hline$X_{38}(1)$ & 0.860 & 0.514 & 2.798 & 1 & 0.094 & 0.423 \\
\hline Constant & 2.801 & 0.606 & 21.366 & 1 & 0.000 & 16.465 \\
\hline
\end{tabular}

Based on Table 3, six questions have a significance value less than 0.05 to be declared valid. The six valid questions consist of question with code $x_{12}, x_{13}, x_{24}, x_{25}, x_{32}$, and $x_{34}$. Based on that condition, the logit model is obtained as follows:

$$
\pi(x)=\frac{e^{\left(2,801+1,013 X_{12}+1,032 X_{13}+1,076 X_{24}+0,966 X_{25}+1,064 X_{32}+0,890 X_{34}\right)}}{1+e^{\left(2,801+1,013 X_{12}+1,032 X_{13}+1,076 X_{24}+0,966 X_{25}+1,064 X_{32}+0,890 X_{34}\right)}}
$$

After obtaining the Logit Model, we must test the logistic regression model using Hosmer's test and Lemeshow to determine whether the model used is appropriate. The appropriate model can be determined by comparing the chi-square value on Hosmer's test and Lemeshow with the chi square's table value. The Hosmer and Lemeshow Test calculation was obtained by entering all of the respondents' answers from 6 declared valid questions on the Wald test.

Percentage of Yes/Agree answers from respondents for valid questions per each variable respectively 35.49 percent for healthy lifestyle behavior variable $\left(X_{1}\right), 69.43$ percent for age variable $\left(X_{2}\right)$, and 59.07 percent for income variable $\left(X_{3}\right)$. From Table 4 , the results as many as 10.3 percent of respondents who answer No/Disagree and 99.4 percent respondents who answer Yes/Agree. Overall determination of the classification of the Logit Model for gluten-free food consumption is 81.3 percent. 
Table 4. Hosmer and Lemeshow Test

\begin{tabular}{|c|c|c|c|c|c|}
\hline & \multirow{3}{*}{ Observed } & & \multicolumn{3}{|c|}{ Predicted } \\
\hline & & & \multicolumn{2}{|c|}{ Variable Y } & \multirow{2}{*}{ Percentage Correct } \\
\hline & & & No & Yes & \\
\hline \multirow[t]{2}{*}{ Step 1} & Variable $Y$ & 0 & 23 & 17 & 10.3 \\
\hline & & 1 & 6 & 53 & 99.4 \\
\hline & Overall Perce & & & & 81.3 \\
\hline
\end{tabular}

Based on the Hosmer and Lemeshow test results in Table 5, the chi-square test value is 6.985, greater than the chi-square table for 0.05 significance level (2.1673). Therefore, based on these calculations, $H_{0}$ is accepted, which means that the Logit model is appropriate for the relationship between gluten-free food consumption and healthy living behavior, age, and income level.

Table 5. Hosmer and Lemeshow Test

\begin{tabular}{llllrr}
\hline Step & Chi-square & Df & \multicolumn{2}{c}{ Sig. } \\
\hline $\mathbf{1}$ & & 6.985 & & 7 & 0.430 \\
\hline
\end{tabular}

\section{Discussions}

This research analyzes the relationship between gluten-free food consumption with healthy living behavior, age, and income level. Based on the finding, healthy living behavior, age, and income level influence gluten-free food consumption partially and simultaneously. Healthy living behavior increase during pandemic covid-19 spread worldwide. Therefore, a healthy lifestyle will maintain immunity during the coronavirus pandemic. Our research findings support previous studies that recommend maintaining physical activity during the coronavirus pandemic that contains a combination of muscle-strengthening exercises such as walking, stair climbing, and performing household (Jakobsson, Malm, Furberg, Ekelund, \& Svensson, 2020). Covid19 also became a point of concern for Human Resource Management during the COVID19 pandemic for employees working in the Formal Indonesian sector. HR management organizations and institutions must explore the repercussions of the new COVID-19 disease beyond an emergency, which requires a dynamic HR framework to manage the growing concerns of all regions of Indonesia. HR management serves as a link between improving public health services' quality above all emergencies requiring experience, training, development, and transformation (Rusilowati, 2020). This research also defines experimental exploration to assist remote HR monitoring strategies.

In the age variable, elderly people will sacrifice enjoyable food such as fast food (Jaye et al., 2018). So elderly people tend to be more careful by consuming healthy food like gluten-free food. Elderly people will monitor their food quality to achieve good condition as growing of their ages. Certain situations and circumstances can impact the decision-making handle. There is the control of "Social Circles of Influence," which implies that personal activities can influence families, social systems, work environment organizations, and communities (Liu et al., 2020). In this case, most of the respondents conceded that their family and co-workers expend gluten-free nourishments and hone a solid way of life. In this manner, we accept that it affects their respondents' utilization. The widespread too empower respondents to require the item. Despite the reality that most respondents are mindful that age cannot directly expend gluten-free foods, consumers see it as a cheap way to preserve wellbeing. China's investigation often bolsters this that social weights unequivocally impact customers. This research also supports the statement that attitude, which consists of age, gender, and pocket money, has a significant positive effect on selecting healthy food (Syah \& Yuliati, 2017).

Even though utilization has expanded compared to recently the widespread, most respondents conceded that the recurrence and amount of their buys are still within the moo run. It is sensible to accept that people who already bought in minor and rare 
amounts are presently buying more habitually and in a more extensive assortment of items. A comparing increment in supply does not meet this increment in request. Amid the widespread, a few generation limitations included imported crude materials, which caused longer lead times due to flight coordination confinements and lockdowns and confinements on large-scale exercises carried out in mechanical city centers (Kardoko, 2020). Subsequently, due to lopsided supply and request, branded items confront a stock deficiency.

Regarding a previous study of Indonesian culinary, selected respondents prefer cheaper food to expensive one (Ernawati \& Suwandojo, 2020). Therefore, it will support that consumers tend to avoid purchasing gluten-free food that price is higher than gluten-contain food. Besides that, as the income gets lower, the purchasing power will decrease, and people do not buy beyond their needs (Hartatin \& Simanjuntak, 2016). Another study mentions that many students consume processed wheat because they taste good at full and affordable prices (Afina \& Retnaningsih, 2018). Therefore, it can be supported that gluten-contain food is cheaper than glutenfree food. Therefore, people tend to consume cheaper foods, exceptionally functional food.

The National Nourishment and Sedate Organization (NFDA) affirms an increment in online shopping for well-being gluten-free nourishments, reliable with the study's discoveries. Tragically, there is no ensure that online commercial center vendors can be trusted. Buyers may have gotten fake gluten-free nourishment or substandard item quality. As a result, the open is empowered to purchase items in grocery stores or through the company's official advanced stages to guarantee that the items gotten and conveyed are honest to goodness and of tall quality.

There are a few restrictions of this consider, such as the nonappearance of coordinated interaction with the respondents, which made the analyst incapable of burrowing more profound into the reasons for devouring gluten-free nourishments. The following confinement is no set time restrain for utilization. There may be a toll in evaluating benefits, either recently or after expending a gluten-free supper. The limitation of this study is the trouble of finding comparative proficiency in substance investigation. Despite the contrasts in a person's way of life and the nourishment devoured, substance examination strategies are still once in a while utilized. The last limitation is research using a non-probability method using convenience sampling which respondents are limited to team's colleagues that our social media can reach.

\section{Conclusions}

Based on the results of hypothesis testing, it can be concluded that a healthy lifestyle, age, and income affect the consumption of gluten-free foods in a population by using a questionnaire or conducting direct interviews. Regarding the analysis, a healthy lifestyle, age, and income positively influence the consumption of gluten-free foods by using a questionnaire.

There is a partially positive influence of healthy lifestyle, age, and income on consuming gluten-free foods in a population using a questionnaire. This indicates that people who do a healthy lifestyle will consume more gluten-free food. In addition, higher-income levels can increase the consumption of gluten-free food, and as people grow older, the desire to consume gluten-free food also increases. All questionnaires develop in binary answers based on the statistical concept, and Logit Model can determine this relationship.

\section{Recommendation}

Future research is expected to analyze healthy living behavior based on its dimensions on the consumption of gluten-free foods. In addition, it can involve the characteristics of the respondent's family to determine the effect of family characteristics on consumption. It uses another brand of gluten-free food commercial that is currently running on television. In addition, further research could involve various occupations in rural villages such as village officials, housewives, traders, or other types of 
workers. Another research can be conducted regarding comparative tests between the healthy level of people who often consume gluten-free foods and those who consume gluten-containing food. The following research can involve specific respondents such as adult people, men or women only, and respondents with certain income levels for respondent characteristics or coverage.

Research has the advantage of combining healthy food consumption habits with healthy lifestyles and other factors in age and income levels. We hope this research can develop healthy food and beverages ecosystem, encourage an increasing quantity of healthy food industry/entrepreneurship and encourage the healthy food industry to enhance their product diversification to attract more consumers. Within an industrial cluster, the healthy food industry is the core industry surrounded by the ecosystem and value chain.

\section{Citation information}

Cite this article as Bastiawan, $\mathrm{H}$., Santoso, S., Sahab, A. I., Yamin, A., \& Almira, B. (2022). Analysis of healthy living behavior, age, and income on gluten-free food consumption. Journal of Consumer Sciences, 7(1), 51-67. doi: https://doi.org/10.29244/jcs.7.1.51 67.

\section{References}

Afina, S., \& Retnaningsih, R. (2018). The influence of students' knowledge and attitude toward functional foods consumption behavior (Pengaruh pengetahuan dan sikap siswa terhadap perilaku konsumsi pangan fungsional). Journal of Consumer Sciences, 3(1), 1-14. doi: https://doi.org/10.29244/jcs.3.1. 1-14

Batista, J., Mariano, I. M., Souza, T., Costa, J., Giolo, J., Cheik, N., \& Puga, G. (2018). The acute effects of mat pilates on hemodynamic and salivary nitrate responses after exercise in postmenopausal women (Efek akut mat pilates pada respon hemodynamic dan nitrate saliva setelah latihan pada wanita pascamenopause). Journal of Aging and Physical Activity, 27, 122. doi: 10.1123/japa.2018-0106

Benzeval, M., Bond, L., Campbell, M., Egan, M., Lorenc, T., Petticrew, M., \& Popham, F. (2014). How does money influence health? project report (Bagaimana uang mempengaruhi kesehatan? laporan proyek). New York(US): Joseph Rowntree Foundation.

Bloom, I., Edwards, M., Jameson, K., Syddall, H., Dennison, E., Gale, C.,
\& Robinson, S. (2016). Influences on diet quality in older age: the importance of social factors (Pengaruh kualitas diet pada usia tua: pentingnya faktor-faktor sosial). Age and Ageing, 46(2), 277-283. doi:

https://doi.org/10.1093/ageing/af w180

Cabanillas, B. (2020). Gluten-related disorders: Celiac disease, wheat allergy, and non-celiac gluten sensitivity (Gangguan terkait gluten: penyakit celiac, alergi gandum, dan sensitivitas terhadap gluten nonceliac). Critical Reviews in Food Science and Nutrition, 60(15), 2606-2621. doi: https://doi.org/10.1080/10408398 .2019 .1651689

Çelebi, C., Gündoğdu, C. \& Kızılkaya, A. (2017). Determination of healthy lifestyle behaviors of high school students (Penentuan perilaku hidup sehat siswa sekolah menengah atas). Universal Journal of Educational Research, 5(8), 1279-1287. doi: https://doi.org/10.13189/ujer.201 7.050801

Chen, P. J., \& Antonelli, M. (2020). Conceptual models of food choice: Influential factors related to foods, individual differences, and society (Model konseptual pilihan makanan: faktor-faktor yang berpengaruh terkait makanan, perbedaan individu, dan masyarakat). Foods, 9(12), 1-21. doi: $10.3390 /$ foods 9121898

Chrysostomou, S., Andreou, S., \& Andreou, Ch. (2019). The development of the gluten free healthy food basket in Cyprus. Is it affordable among low-income adults diagnosed with celiac disease? (Pengembangan kelompok 


\section{$\begin{array}{llllllllll}J & O & U & R & N & A & L & 0 & F\end{array}$ CONSUMER SCIENCES}

makanan sehat bebas gluten di Siprus. apakah terjangkau oleh orang dewasa berpenghasilan rendah yang didiagnosis mengidap penyakit celiac?). Journal of public health (Oxford, England), 42(2). 270-276. doi: 10.1093/pubmed/fdz034

Cockerham, W., Wolfe, J. D., \& Bauldry, S. (2019). Health lifestyles in late middle Age (Gaya hidup sehat di akhir Abad Pertengahan). Sage Journals, 42(1), 34-46. doi:

https: / /doi.org/10.1177/01640275 19884760

Czaja-Bulsa, G., \& Bulsa, M. (2017). What do we know now about IgEmediated wheat allergy in children? (Apa yang sekarang kita ketahui tentang alergi gandum bermedia IgE pada anak-anak?). Nutrients, 9(1), 1-9. doi: $10.3390 /$ nu9010035

Dunneram, Y., \& Jeewon, R. (2015). Determinants of eating habits among older adults. Progress in Nutrition, 17(4), 274-283

FDA Consumer Health Information/U.S. Food and Drug Administration. (2013). What is gluten free? FDA has an answer. Retrieved from https://www.fda.gov/food/nutriti on-education-resourcesmaterials/gluten-and-foodlabeling.

Ernawati, H., \& Suwandojo, D. P. H. (2019). Consumer preferences for Indonesian culinary (Preferensi konsumen terhadap kuliner Indonesia). Journal of Indonesian Economy and Business, 34(3), 280 293. doi: $10.22146 /$ jieb. 52637

Ford, K., Hughes, K., Gee, I., McHale, P., Prickett, L., Page, Y., \& Bridgman, S. (2014). Guernsey and Alderney healthy lifestyle survey 2013 (Survei gaya hidup sehat Guernsey dan Alderney 2013). Retrieved from https: / /www.researchgate.net/pu blication/271512707

French, S. A., Tangney, C. C., Crane, M. M., Wang, Y., \& Appelhans, B. M. (2019). Nutrition quality of food purchases varies by household income: the SHoPPER study (Kualitas gizi pembelian makanan bervariasi menurut pendapatan rumah tangga: studi SHOPPER). BMC Public Health, 19:231, 1-7. https: / / doi.org/10.1186/s12889 019-6546-2

Fry, L., Madden, A., \& Fallaize, R. (2018). An investigation into the nutritional composition and cost of gluten-free versus regular food products in the UK (Investigasi komposisi nutrisi dan biaya antara produk makanan bebas gluten dan produk makanan biasa di Inggris). Journal of Human Nutrition and Dietetics, 31(1), 108-120. doi: https://doi.org/10.1111/jhn.12502

Gujral, N., Freeman, H. J., \& Thomson, A. B. R. (2012). Celiac disease: prevalence, diagnosis, pathogenesis and treatment (Penyakit celiac: prevalensi, diagnosis, patogenesis dan pengobatan). World J. Gastroenterol, 18(42), 6036-6059. doi:

https: / /dx.doi.org/10.3748/wjg.v1 8.i42.6036

Hartatin, D., \& Simanjuntak, M. (2016). The effect of value and reference group on young consumer's hedonic buying (Pengaruh nilai dan kelompok referensi pada pembelian hedonis konsumen muda). Journal of Consumer Sciences, 1(1), 33-46. doi:

https://doi.org/10.29244/jcs.1.1. 33-46

Helldán, A., Lallukka, T., Rahkonen, O., \& Lahelma, E. (2011). Changes in healthy food habits after transition to old age retirement (Perubahan kebiasaan makan sehat setelah transisi ke masa pensiun). European Journal of Public Health, 22(4), 582-586. doi: 10.1093/eurpub/ckr060

Jakobsson, J., Malm, C., Furberg, M., Ekelund, U., \& Svensson, M. (2020). Physical activity during the coronavirus (COVID-19) pandemic: prevention of a decline in metabolic and immunological functions (Aktivitas fisik selama pandemi virus corona (COVID-19): pencegahan penurunan fungsi metabolisme dan imunologis). Frontiers in sports and active living, 2(57), 1-4. doi: https://doi.org/10.3389/fspor.202 0.00057

Jaye, C., Young, J., Egan, R., Llewellyn, R., Cunningham, W., \& Radue, P. (2018). The healthy lifestyle in longevity narratives 


\section{J O U R N A L O F CONSUMER SCIENCES}

(Gaya hidup sehat dalam narasi umur panjang). Social Theory Health, 16(1), 1-18. doi: 10.1057/s41285-018-0062-9

Kardoko, H. (2020). Revolusi industri farmasi di tengah pandemi Covid19 (The pharmaceutical industry revolution in the midst of the Covid-19 pandemic). Retrieved from

https: / /ekonomi.bisnis.com/read/ 20201022/257/1308478/revolusiindustri-farmasi-di-tengahpandemi-covid-19.

Khoury, D. E., Balfour-Ducharme, S., \& Joye, I. (2018). A review on the gluten-free diet: technological and nutritional challenges (Ulasan tentang diet bebas gluten: tantangan teknologi dan nutrisi). Nutrients, 10(10), 1-25. doi: https://doi.org/10.3390/nu101014 10

Klieštik, T., Kočišová, K., \& Mišanková, M. (2015). Logit and probit model used for prediction of financial health of company (Model logit dan probit untuk memprediksi kesehatan keuangan perusahaan). Procedia Economics and Finance, 23, 850-855.

https: / /doi.org/10.1016/S22125671(15)00485-2

Kocak, D. Y. (2017). Effect of pender's healthy life style training, which is applied in the direction of health promotion model, on eliminating the menopausal symptoms (Pengaruh pelatihan gaya hidup sehat pender yang diterapkan dalam arah model promosi kesehatan dalam menghilangkan gejala menopause). [Doctoral Theses]. Istanbul: Istanbul University.

Lambert, K. \& Ficken, C. (2015). Cost and affordability of a nutritionally balanced gluten-free diet: is following a gluten-free diet affordable? (Biaya dan keterjangkauan dari diet bebas gluten yang bergizi seimbang: apakah menjalankan diet bebas gluten terjangkau?). Nutrition \& Dietetics; Journal of Dietetians Australia, 73(1), 36-42. doi: 10.1111/1747-0080.12171

Lesakova, D. (2018). Health perception and food choice factors in predicting healthy consumption among elderly (Persepsi kesehatan dan faktor pilihan makanan dalam memprediksi konsumsi sehat di kalangan lanjut usia). Acta Universitatis Agriculturae et Silviculturae Mendelianae Brunensis, 66(6), 1527-1534. doi: 10.11118/actaun201866061527

Lobo, R.A., Davis, S., Villiers, T.D., Gompel, A., Henderson, V., Hodis, H.N., \& Baber, R. (2014).

Prevention of diseases after menopause (Pencegahan penyakit setelah menopause). Climacteric, 17(5), 540-556. doi: 10.3109/13697137.2014.933411

Lockie, S, K. Lyons, G Lawrence, J. Gricec. (2004). Choosing organics: a path analysis of factors underlying the selection of organic food among australian consumers (Memilih organik: analisis jalur faktor yang mendasari pemilihan makanan organik di antara konsumen Australia). Appetite, 43(2), 135-146. doi: https://doi.org/10.1016/j.appet.2 004.02.004

Littlejohns, T.J., Chong, A.Y., Allen, N.E., Arnold, M., Bradbury, K.E., Mentzer, A.J., \& Carter, J.L. (2021). Genetic, lifestyle, and health-related characteristics of adults without celiac disease who follow a gluten-free diet: a population-based study of 124,447 participants (Genetik, gaya hidup, dan karakteristik terkait kesehatan orang dewasa tanpa penyakit celiac yang mengikuti diet bebas gluten: sebuah studi berbasis populasi dari 124.447 peserta). The American Journal of Clinical Nutrition, 113(3), 622-629. doi: https: / /doi.org/10.1093/ajcn/nqa a291

Liu, X., Luo, W. T., Li, Y., Li, C. N., Hong, Z. S., Chen, H. L., ... Xia, J. Y. (2020). Psychological status and behavior changes of the public during the COVID19 epidemic in China (Status psikologis dan perubahan perilaku masyarakat selama epidemi COVID-19 di Cina). Infectious Diseases of Poverty, 9(58), 1-11. doi: https://doi.org/10.1186/s40249020-00678-3

Markets and Markets. (2021). Glutenfree products market by type (bakery products, snacks \& rte products, condiments \& dressings, pizzas \& pastas), distribution channel (conventional stores, 


\section{J 0 O U R R N A L CONSUMER SCIENCES}

specialty stores and drugstores \& pharmacies), form \& region global forecast to 2025. Retrieved from

https: / / www.marketsandmarkets. com/Market-Reports/gluten-freeproducts-market-738.html.

Pinto-Sanchez, M. I. \& Verdu, E. F. (2018). Non-celiac gluten or wheat sensitivity: it's complicated! (Sensitivitas gluten atau gandum non-celiac: rumit!).

Neurogastroenterology \& Motility, 30(8), e13392. doi:

$10.1111 / \mathrm{nmo} .13392$

Marmot, M. (2002). The influence of income on health: views of an epidemiologist (Pengaruh pendapatan terhadap kesehatan: pandangan seorang ahli epidemiologi). Health Affairs, 21(2), 31-46. doi:

10.1377/hlthaff.21.2.31

Masih, J. \& Sharma, A. (2016). Study on consumer behaviour and economic advancements of glutenfree products (Studi perilaku konsumen dan kemajuan ekonomi produk bebas gluten). American Journal of Experimental Agriculture, 12(1), 1-10. doi: 10.9734/AJEA/2016/24737

Ministry of Health of the Republic of Indonesia. (2020). Guidelines for the prevention and control of the corona virus disease (Covid 19) revised 4th. Jakarta: Directorate General of Disease Prevention and Control.

Morris, J., Wilkinson, P., Dangour, A. D., Deeming, C., \& Fletcher, A. (2007). Defining a minimum income for healthy living (MIHL): older age, England (Mendefinisikan pendapatan minimum untuk hidup sehat (MIHL): usia yang lebih tua, Inggris). International Journal of Epidemiology, 36(6), 1300-1307. doi: https://doi.org/10.1093/ije/dym1 29

Morris, J. N., Donkin, A. J. M., Wonderling, D., Wilkinson, P., \& Dowler, E.A. (2000). A minimum income for healthy living (Penghasilan minimal untuk hidup sehat). Journal of Epidemiology and Community Health, 54(12), 885-889. doi: http://dx.doi.org/10.1136/jech.54 .12 .885
Motegi, H., Nishimura, Y., \& Terada, K. (2016). Does retirement change lifestyle habits? (Apakah pensiun mengubah kebiasaan gaya hidup?). The Japanese Economic Review, 67(2), 169-191. doi: $10.1111 /$ jere. 12104

Myhrstad, M. C., Slydahl, M., Hellmann, M., GarnweidnerHolme, L., Lundin, K. E. A., Henriksen, C., \& Telle-Hansen, V. H. (2021). Nutritional quality and costs of gluten-free products: a case-control study of food products on the Norwegian marked (Kualitas nutrisi dan biaya produk bebas gluten: studi kasus produk makanan berlabel Norwegia). Food \& Nutrition Research, 65:6121, 1 10. doi: https://doi.org/10.29219/fnr.v65. 6121

Nugroho, H.P., \& Nikmah, F. (2018). Pengaruh gaya hidup dan positive word of mouth terhadap keputusan pembelian produk tepung bebas gluten Ladang Lima (The influence of lifestyle and positive word of mouth on purchasing decisions of Ladang Lima gluten-free flour products). Jurnal Aplikasi Bisnis, 4(2), 509-513. E-ISSN: 2407-5523.

Perrin, L., Allès, B., Buscail, C., Ravel, C., Hercberg, S., Julia, C., \& Kesse-Guyot, E. (2019). Glutenfree diet in french adults without coeliac disease: sociodemographic characteristics, motives and dietary profile (Diet bebas gluten pada orang dewasa perancis tanpa penyakit celiac: karakteristik sosiodemografi, motif, dan profil diet). British Journal of Nutrition, 122(2), 231-239 doi:10.1017/S0007114519001053.

Redata, L., Kezia, R., Solaiman, K.H, \& Santoso, S. (2021). Analisis korelasi pendampingan komunitas terhadap inovasi pelaku ekonomi kreatif dan pemenuhan kebutuhan konsumen: Studi kasus pada komunitas tangerang berdaya dan pelaku ekonomi kreatif kuliner Tangerang (Correlation analysis of community assistance on creative economy actors' innovation and meeting consumer needs: A case study on the empowered Tangerang community and Tangerang's culinary creative economy actors). Business 


\section{J O U R N A L O F CONSUMER SCIENCES}

Management Journal, 17(1), 1-19. doi:10.30813/bmj

Rusilowati, U. (2020). Praktek manajemen sumber daya manusia selama pandemi covid-19 pada karyawan yang bergerak di sektor formal di Indonesia (Human resources management practices during the Covid-19 pandemic on employees moving in the formal sector in Indonesia). Jurnal Ilmiah MEA (Manajemen, Ekonomi dan Akuntansi), 4(2), 481-491. doi: https: / /doi.org/10.31955/mea.vol 4.iss2.pp481-491

Sabença, C., Ribeiro, M., Sousa, T. de, Poeta, P., Bagulho, A. S., \& Igrejas, G. (2021). Wheat/glutenrelated disorders and gluten-free diet misconceptions: a review (Gangguan terkait gandum/gluten dan kesalahpahaman diet bebas gluten: sebuah tinjauan). Foods, 10(8), 1765. Doi: $10.3390 /$ foods 10081765

Šálková, D. \& Hes, A. (2015). Glutenfree food - the influence of selected qualitative characteristics on consumer decision making of coeliacs in hospitality establishments (Makanan bebas gluten - pengaruh pemilihan karakteristik kualitatif pada pengambilan keputusan konsumen celiac di perusahaan perhotelan). Czech Journal of Food Sciences, 33(6), 513-517. doi: 10.17221/113/2015-CJFS

Santoso, S. (2010). Model logit (logistic regression) sebagai model probabilitas linier alternatif, dalam contoh aplikasi teknik industri (logistic regression as an alternative linear probability model, in the example of industrial engineering applications). Jurnal Teknik Industri, 2(1), 59-64. doi: https: / /doi.org/10.22219/JTIUMM. Vol2.No1.59-64

Santoso, S. (2020). Optimizing access to financial capital of creative economy for startups towards global competitiveness (Optimalisasi akses modal finansial ekonomi kreatif untuk startup menuju daya saing global). BECOSS (Business Economic, Communication, and Social Sciences), 2(2), 13-21. doi: https://doi.org/10.21512/becossjo urnal.v2i2.6246
Santoso, S., Natanael, A., Griselda, A., Khoirunnisa, J., Simanjuntak, M., Bagus, R., \& Fatmawati, A. (2021). Analisis pengembangan platform ekspor sub sector kuliner tinjauan dari model sistem inovasi Analysis of the development of the culinary sub-sector export platform, an overview of the innovation system model). Jurnal Distribusi, 9(1), 29-38. doi: 10.29303/distribusi.v9i1.151

Santoso, S., Natanael, A., Griselda, A., Khoirunnisa, J., Simanjuntak, M., Bagus, A., \& Merry, L. Z. (2021). Analysis of business process reengineering and export platform in supporting business exports of creative economy players in the micro, small and medium business in culinary sub-sector (Analisis rekayasa ulang proses bisnis dan platform ekspor dalam mendukung ekspor usaha pelaku ekonomi kreatif pada usaha mikro, kecil, dan menengah sub sektor kuliner). Journal of Economics, Business, and Government Challenges (JoEBGC), 4(1), 32-49. doi: 10.33005/ebgc.v4i1.170

Sugiyono. (2017). Statistika untuk Penelitian [Statistics for Research]. Bandung(ID): Penerbit Alfabeta.

Sutanto, L., Lukito, W., \& Basrowi, R. W. (2020). Nutrition interventions for healthy ageing in Indonesia (Intervensi nutrisi untuk penuaan yang sehat di Indonesia). Amerta Nutrition, 4(1), 1-5. doi: 10.20473/amnt. v4i1SP.2020.1-5 1

Syah, A., \& Yuliati, L. N. (2017). The influence of values and attitude toward healthy food selection at student of Bogor Agricultural University (Pengaruh nilai dan sikap terhadap pemilihan makanan sehat pada mahasiswa Institut Pertanian Bogor). Journal of Consumer Sciences, 2(2), 57-65. doi: https: //doi.org/10.29244/jcs.2.2. 57-65

Viscecchia, R., Stasi, A., Nardone, G., Devitiis, B. D., \& Baselice, A. (2016). Supplements consumption, health oriented behaviour and beyond (Konsumsi suplemen, perilaku berorientasi kesehatan dan seterusnya). Rivista Economia Agraria, 71(1), 256-265. doi: 
https://doi.org/10.13128/REA18645

Wielsøe, M., Berthelsen, D., Mulvad, G., Isidor, S., Long, M., \& Bonefeld-Jørgensen, E. C. (2021). Dietary habits among men and women in West Greenland: followup on the ACCEPT birth cohort (Kebiasaan diet di antara pria dan wanita di West Greenland: tindak lanjut pada kelompok kelahiran ACCEPT). BMC Public Health, 21:1426, 1-17. doi: https: / /doi.org/10.1186/s12889021-11359-7

World Health Organization (WHO). Regional Office for Europe. (1999). Healthy living: what is a healthy lifestyle? (Hidup sehat: apa itu gaya hidup sehat?). WHO Regional Office for Europe, Copenhagen. Retrieved from

https: / /apps.who.int/iris/handle/ 10665/108180.

Zoumpopoulou, G \& Tsakalidou, E. (2019). The role of alternative and innovative food ingredients and products in consumer wellness chapter 8, pages 213-237 (Peran bahan dan produk makanan alternatif dan inovatif dalam kesehatan konsumen bab 8). San Diego: Academic Press. Doi: https: / / doi.org/10.1016/B978-012-816453-2.00008-5 